\title{
Safety and quality assurance for geotechnical constructions in urban areas
}

\author{
Steffen Leppla ${ }^{1}$, Rolf Katzenbach ${ }^{2}$ \\ Ingenieursozietaet Professor Dr.-Ing. Katzenbach GmbH, Frankfurt am Main, Germany \\ E-mail: 'leppla@katzenbach-ingenieure.de (corresponding author)
}

\begin{abstract}
Safety and quality assurance are the most important aspects for the design and the construction of geotechnical structures. These aspects consider the optimisation by reducing the resources material, money and time. For construction projects with a distinctive soil-structure interaction in the vicinity of existing structures special methods have to be applied to guarantee safety and quality. Therefor numerical simulations using the Finite-Element-Method (FEM), insitu load tests on the construction site, special foundation techniques like the Combined Pile-Raft Foundation (CPRF), the observational method and an independent peer review are necessary. The paper explains the application and the combination of these tools by examples from engineering practice.
\end{abstract}

Keywords: soil-structure interaction, Combined Pile-Raft Foundation, load test, peer review.

\section{Introduction}

The basis of the safety and quality assurance of geotechnical structures is the analysis of the soil-structure interaction. Therefor an adequate soil investigation and numerical simulations using the Finite-Element-Method (FEM) are necessary. Two- and three-dimensional numerical simulations have to consider the stiffness of structures and the non-linear material behaviour of the soil. For the sensitivity analysis the mechanical soil parameters should be varied. A calibration of the numerical simulations is essential for a precise prediction of stresses and displacements resp. differential displacements. The calibration can be carried out e.g. by back analysis of an in-situ load test.

The theoretical analysis has always to be combined with the observational method to check the occurring displacements and to detect critical developments of the displacements resp. differential displacements as early as possible. The theoretical analysis, the soil investigation including in-situ load tests and the construction phase has to be checked by an independent peer review combined with an adequate monitoring program.

\section{Observational method}

The observational method is a verification procedure which was introduced by the building authorities. Compared to other construction materials like concrete or steel this method takes into account the difficulty and probably not sufficient specifications and descriptions of the soil material behaviour.

The observational method is a combination of geotechnical investigations and analysis with a metrological supervision during the construction phase and, if necessary, during the service phase. Critical situations have to be controlled by suitable technical measures. The observational method is a precise monitoring procedure to verify the soil and rock mechanical behaviour as well as the quality and safety during the construction phase (Figure 1).

The application of the observational method leads to a verification of the usability and the validation of the theoretical models and to a quality assurance during the construction phase. In accordance to the current technical standards and regulations the observational method is state-of-the-art for construction projects with significant geotechnical difficulties (geotechnical category GC 3 according to Eurocode 7) Examples are construction projects with a distinct soilstructure interaction like high-rise buildings, tunnels, dams and bridges.

The application limit of the observational method is reached in cases of brittle failure resp. non-sufficient ductility. Also it is important, that the observational method as a single element of the analysis of the stability and the serviceability is not sufficient and not permitted. By definition, the observational method consists of geotechnical investigations, analysis and design combined with metrological supervision, which may be described as monitoring. 


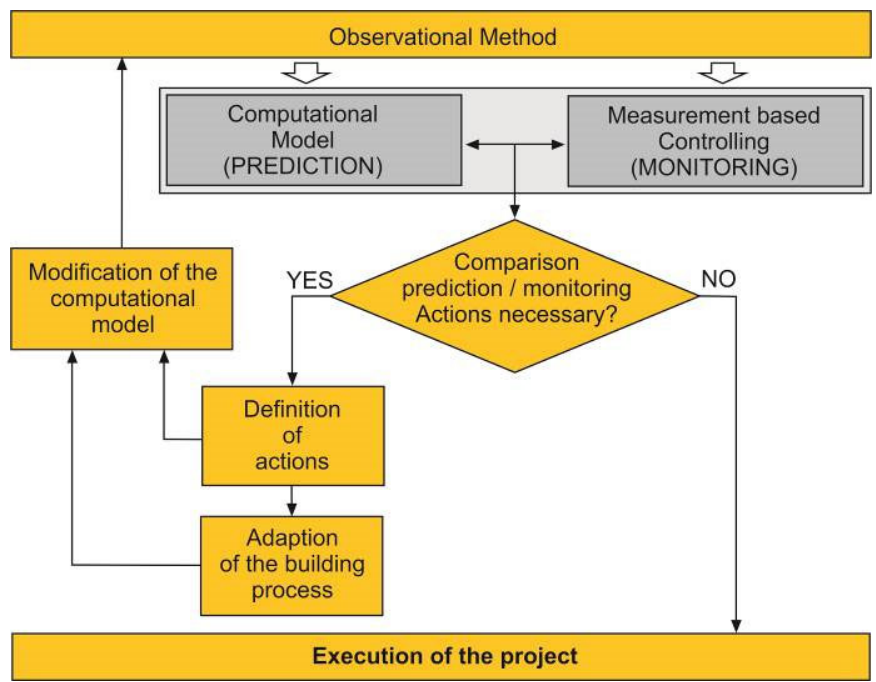

Figure 1. Observational method

For further information about the observational method see Katzenbach et al. (Katzenbach, Bachmann, Leppla \& Ramm, 2010; Katzenbach, Leppla \& Choudhury, 2016).

\section{Independent peer review}

For safety aspects an independent peer review and monitoring during planning, design and construction is necessary. The independent peer review should be carried out by a publicly certified independent expert. These independent experts can be defined for structural engineering, fire prevention, technical facilities and installations and geotechnical engineering.

\begin{tabular}{|l|l|}
\hline 1 & Assignment \\
\hline 2 & Handover of the planning/design \\
\hline 3 & Request for building permission \\
\hline 4 & Assignment of publicly certified experts \\
\hline 5 & Result of the peer review process \\
\hline 6 & Building permission \\
\hline 7 & Transfer of building permission \\
\hline 8 & Planning for construction \\
\hline 9 & Information about start of construction \\
\hline 10 & Independent supervision of the construction process \\
\hline
\end{tabular}

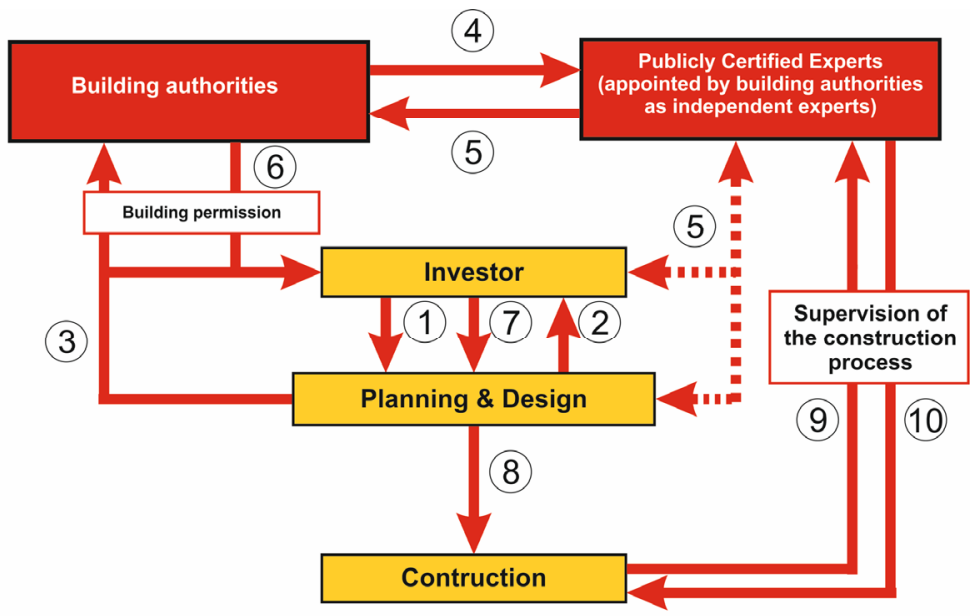

Figure 2. Independent peer review

The publicly certified independent experts verify and certify the compliance of the current standards and regulations in their specific field of work. Publicly certified independent experts for geotechnics verify and certify the completeness and accuracy of the soil investigation (stratigraphy, soil parameters, groundwater conditions, bearing capacity, stiffness etc.) and the planning, design and construction of foundation systems, retaining structures, tunnels etc. An accurate description, evaluation and handling of the soil and rock parameters in planning, design and construction is essential and has in difficult cases a big importance during the service phase after construction.

The independent peer review of civil engineering consists of three major parts which are shown in Figure 2. Investors, experts for planning and design and the construction companies belong to the first part. Planning and design are based on the current standards and regulations and are parts of the request for the building permission. The building authorities are the second part and check independently the compliance of the planning to the building law. The building authorities are responsible for the independent supervision of all legal aspects. The third part consists of the publicly certified independent experts. They are responsible for the independent peer review of all engineering aspects during planning, design and construction. 


\section{In-situ pile load tests}

Project- and site-related soil investigations with core drillings and laboratory tests are essential for the initial definition of soil mechanical properties of the single soil layers. But usually these investigations are not sufficient for an entire and realistic capture of the complex conditions, caused by the interaction of subsoil and construction (Katzenbach, 2005). In order to reliably determine the ultimate bearing capacity of piles, load tests need to be carried out (Briaud, Ballouz \& Nasr, 2000). For pile load tests often very high counter weights or strong anchor systems are necessary. By using the Osterberg method high loads can be reached without installing anchors or counter weights. Hydraulic jacks, so called O-cells, induce the load in the pile using the pile itself partly as abutment. Figure 3 shows the principle scheme of pile load tests. For hybrid foundation systems like Combined Pile-Raft Foundationes (CPRF) load test are a very good basis for the calibration of the numerical simulations by back-analysis.

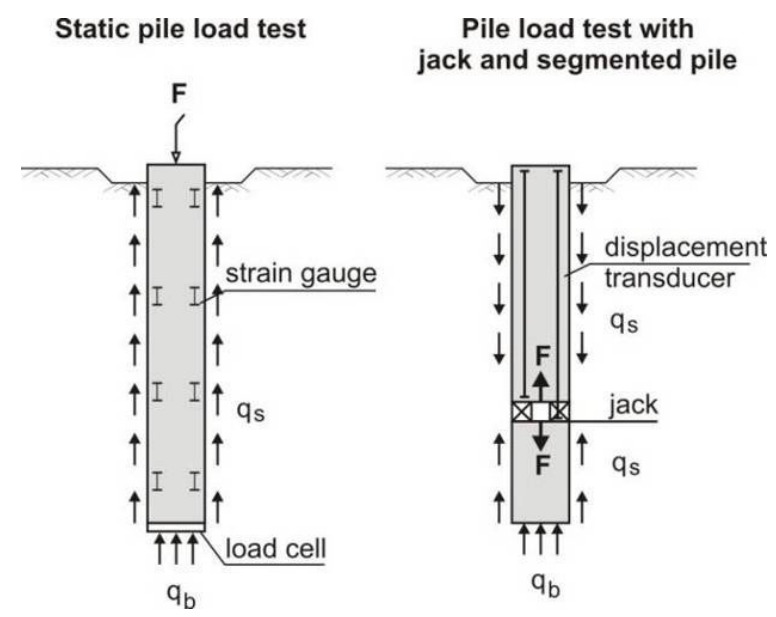

Figure 3. Principle scheme of pile load tests

\section{High-rise building in difficult soil and groundwater conditions}

\section{Project overview}

A high-rise building with a height of more than $75 \mathrm{~m}$ in settlement sensitive soil has been constructed at the coastline of West Africa. The high-rise building has up to 16 storeys. The foundation system is designed as a Combined Pile-Raft Foundation (CPRF). The annex buildings are up to $60 \mathrm{~m}$ high and include apartments and parking levels. All structures have one basement level. The whole structure has a total load of more than $700 \mathrm{MN}$. Due to its complexity the project is categorized into the Geotechnical Category GC 3 of the Eurocode 7 (CEN, 2008). The Geotechnical Category GC 3 is the category for the most difficult projects. The design and application of the CPRF as a hybrid foundation system is explained in Katzenbach et al. (Katzenbach et al., 2016).

\section{Soil and groundwater conditions}

The soil investigation was carried out down to a depth of $80 \mathrm{~m}$ below the surface. The soil and groundwater conditions can be summarised as follows:

$-0 \mathrm{~m}$ to $30.5 \mathrm{~m}$ : alternating sequence of loose, medium dense and dense sand layers;

-30.5 to $80 \mathrm{~m}$ : alternating sequence of medium dense/dense sand layers and clay/silt layers with low to high plasticity;

- groundwater level is close to the surface.

\section{Foundation system}

Due to the difficult boundary conditions the foundation system is designed as a Combined Pile-Raft Foundation (CPRF). The principle design and the load-settlement behaviour of a CPRF is explained in detail in Katzenbach et al. (Katzenbach et al., 2016).

For the calibration of the numerical simulations a pile load test with O-cells has been used. The O-cells have been activated differently to determinate the base resistance and the skin friction of pile segments in different soil layers. For determination of the skin friction and the and the base resistance of pile segment 3 only the lower O-cell was activated using the segment 2 as abutment. For determination of the skin friction of pile segment 2 the upper O-cell was activated and the lower O-cell was released. Pile segment 1 is the abutment for this test phase. For determination of the skin friction of pile segment 1 the upper O-cell was loaded and the lower O-cell was closed. The pile segments 2 and 3 are used as abutments. Figure 4 shows on the left the mesh of the FEM-simulations and the principle arrangement of the pile load test equipment with the 3 pile segments and the upper and lower O-cells. 


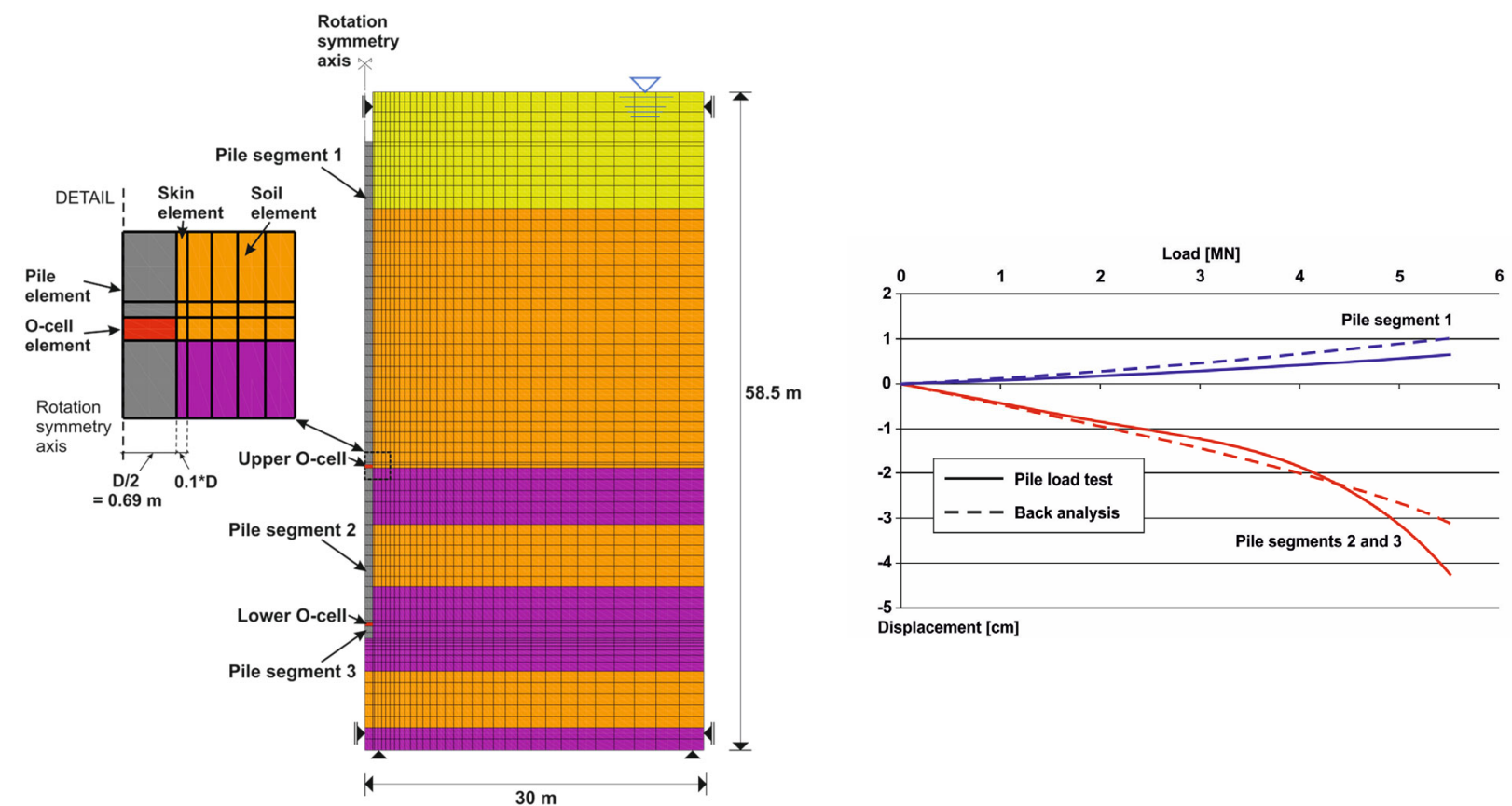

Figure 4. FEM-simulation of pile load test (left) and measurement and calculation results (right)

The results of the back analysis by FEM-simulations are the basis for the adjustment of the estimated soil parameters and were used to verify the developed, simplified stratigraphy for the analysis of the whole foundation system. The results of the pile load test in-situ and of the back analysis are drawn in Figure 4 on the right. The comparison of the results shows a good accordance.

The whole foundation system was designed by 3-dimensional, non-linear FEM-simulations. The length, the diameter and the number of the piles were optimized by the FEM-simulations and adapted to the bearing capacity and the load-settlement behaviour of the CPRF. Figure 5 shows the final CPRF design illustrated by the FEM-simulation. The pile diameter is $1.5 \mathrm{~m}$. The maximum length is $37 \mathrm{~m}$. The CPRF coefficient is $\alpha_{\mathrm{CPRF}}=0.8$. That means, that $80 \%$ of the total building load are carried by the piles and $20 \%$ of the total building load is carried by the foundation raft. During the construction phase and for the first years of service time the loads of the piles, stresses under the raft and the deformation behaviour of the CPRF are measured by a monitoring program according to the requirements of the observational method.

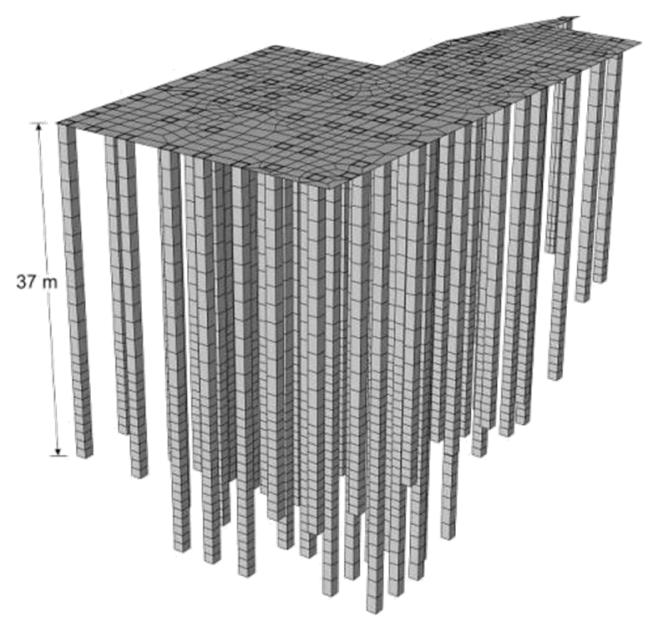

Figure 5. Final CPRF

\section{Deep excavation and high-rise building next to underground sturctures}

\section{Project overview}

South-west of the centre of Frankfurt am Main, Germany, a new building complex was realised on a construction site with $21,000 \mathrm{~m}^{2}$. An overview and a cross section of the project area are given in Figure 6 . The new building complex is situated nearby the historic monastery in the east, the rive Main in the south, metro tunnels in the west and 
the north as well as a street tunnel in the north. The building complex consists of 6 parts, 4 of them are high-rise buildings.

Regarding the complex construction process in several steps and the soil-structure interaction between existing buildings, new buildings, the metro and street tunnels and an existing sewer line, the project is classified into the Geotechnical Category GC 3 according to EC 7 (CEN, 2008). Depending on the superstructures and the loads in the foundation system of the building complex varies from spread foundations, classic pile foundations, micropiles to a Combined Pile-Raft Foundation (CPRF).
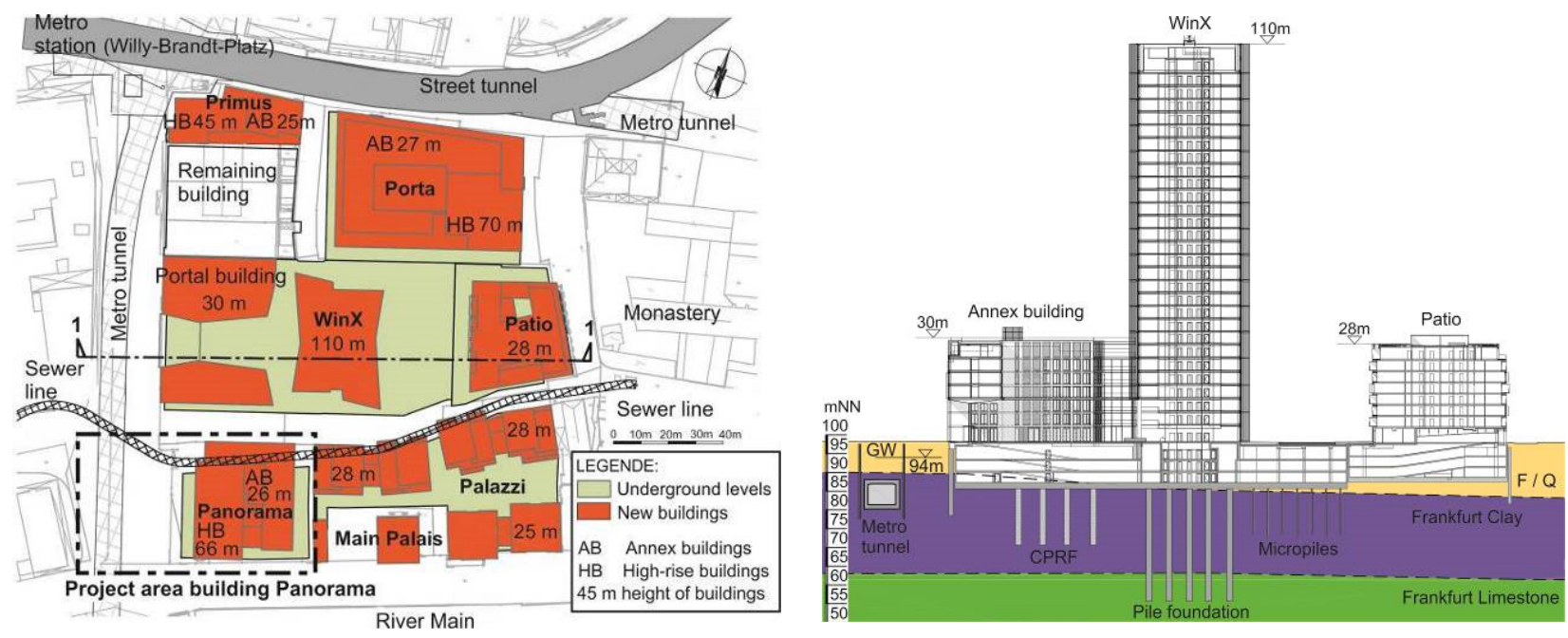

Figure 6. Overview of the project area (left) and cross section 1-1 (right)

\section{Soil and groundwater conditions}

The soil and groundwater conditions can be summarised as follows:

- filling with a thickness of $2 \mathrm{~m}$ to $10 \mathrm{~m}$;

- quaternary sand and gravel down to $11 \mathrm{~m}$ under surface with a thickness of $1 \mathrm{~m}$ to $9 \mathrm{~m}$;

- tertiary Frankfurt Clay, consisting of alternating layers of clay, limestone and sand, down to $35 \mathrm{~m}$ under the surface;

- Frankfurt Limestone;

- upper groundwater level is in a depth between $4 \mathrm{~m}$ and $6.5 \mathrm{~m}$ below the surface;

- lower groundwater aquifer is located in the Frankfurt Clay.

\section{Calibration of the numerical simulations}

Due to the difficult soil and groundwater conditions, the load situations and the required minimisation of the deformations of the underground structures the numerical simulations had to be calibrated. Therefor the numerical simulations were calibrated by back analysis of two pile load tests that had been carried out on the construction site. The setup of pile load test TP 1 is shown in Figure 7 on the left. TP 1 ends in the Frankfurt Clay. TP 2 ends in the Frankfurt Limestone. The load on the piles was given by O-cells. The test piles consist of the upper, the middle and the lower pile segments, separated by the upper and the lower O-cells.
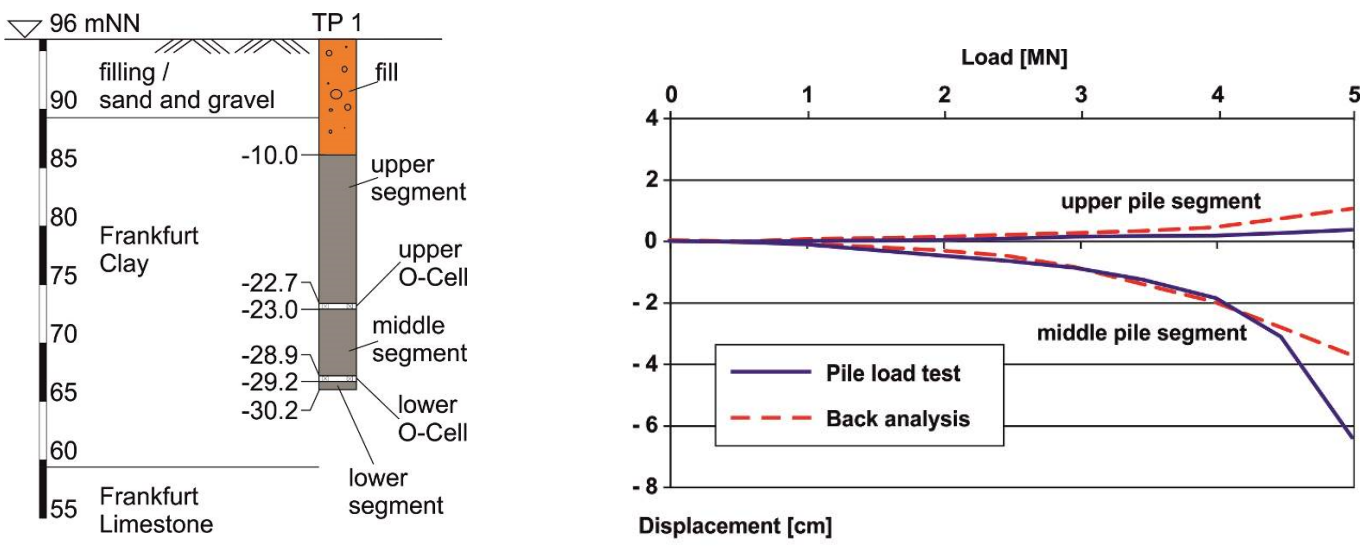

Figure 7. Setup of pile load test TP 1 (left) and measurement and calculation results (right) 
The test piles were equipped with measurement devices:

- strain gauges in the upper, the middle and the lower pile segment;

- stack extensometer from the surface to the pile top, to the upper O-cell, to the lower O-cell and to the pile toe;

- extensometer between the O-cells;

- displacement transducer inside the O-cells.

Using the back analysis of the pile load test the developed numerical simulations were calibrated. Figure 7 shows on the right the measured displacements of the pile load test in-situ and the calculated displacements of the back analysis in one of the test phases. The soil mechanical parameters, detected during the soil investigation, were updated according to the results of the back analysis. Th calibration is the basis for the following 2-dimensional and 3-dimensional numerical simulations.

\section{Numerical simulations for the metro tunnel in the west}

For the determination of the complex soil-structure interaction between existing buildings, new buildings, the metro and street tunnels and the sewer line, several 2-dimensional and 3-dimensional, non-linear numerical simulations have been carried out. Figure 8 shows one of the 3-dimensional models, which is for the south-west of the project area with the building Panorama.

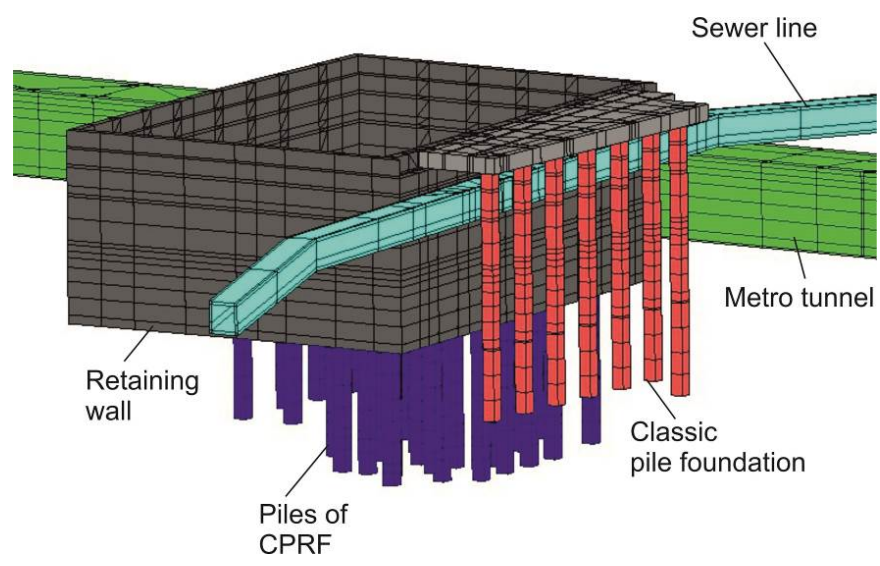

Figure 8. 3-dimensional numerical model of the area of the building Panorama, view from the north-east

The foundation system of this part of the project area combines a CPRF and a classic pile foundation. It has to be guaranteed that the existing sewer line does not get any load from the new buildings. For the reduction of the deformation of the sewer line the retaining structure does not get any load from the new buildings. For the settlement relevant loads the predicted settlements of the building are up to a maximum of $3 \mathrm{~cm}$. The predicted settlements of the sewer line are smaller than $1.5 \mathrm{~cm}$. The piles of the CPRF have a diameter of $1.5 \mathrm{~m}$ and a length between $14 \mathrm{~m}$ and $20 \mathrm{~m}$. The CPRF coefficient is $\alpha_{\mathrm{CPRF}}=0.6$ according to the CPRF-Guideline (ISSMGE, 2013). This means that $60 \%$ of the total building load are carried by the piles and $40 \%$ of the total building load are carried by the foundation raft. The piles of the classic pile foundation have a diameter of $1.5 \mathrm{~m}$ and a length between $20 \mathrm{~m}$ and $24 \mathrm{~m}$.

The retaining system of the excavation in the main area consisted of bored piles. The bored pile walls had a diameter of $88 \mathrm{~cm}$ and were stabilised by struts and anchors. The maximum depth of the excavation is $14.3 \mathrm{~m}$. The distance between the retaining system and the metro tunnel was between $11 \mathrm{~m}$ and $20 \mathrm{~m}$.

To get more detailed information about the deformations and the variation and distribution of stresses on the tunnel during the different construction phases and the influence on its sealing system, several 2-dimensional numerical simulations have been carried out. For the study of the sensitivity of the metro tunnel the soil parameters have been varied. The different construction phases were:

- construction of the retaining system;

- different excavation stages;

- different construction stages of the superstructure;

- service phase of the building complex.

Figure 9 shows on the left the iso-lines of the calculated horizontal displacements. The maximum calculated horizontal displacement of the retaining system is $2.1 \mathrm{~cm}$. The maximum calculated horizontal displacement of the metro tunnel is $1.4 \mathrm{~cm}$.

Figure 9 shows on the right the iso-lines of the calculated vertical displacements. The maximum calculated vertical displacement of the retaining system is $1 \mathrm{~cm}$. The maximum calculated vertical displacement of the metro tunnel is $0.2 \mathrm{~cm}$. 

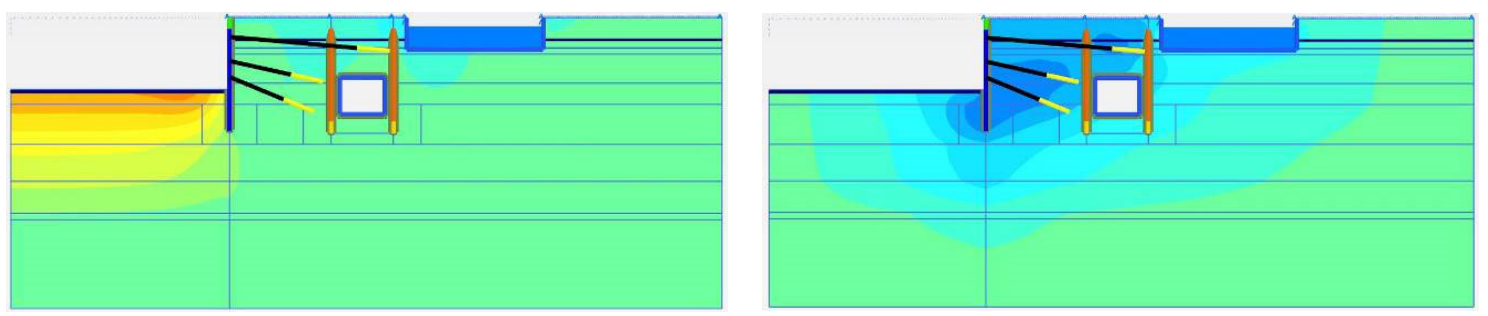

Figure 9. Calculated Iso-lines of the horizontal displacements (left) and the vertical displacements (right)

The differential displacements at the joint of the tunnel blocks have been expected in the range of a few millimetres.

In addition to the analysis of the serviceability of the metro tunnel the stability was checked. The comparison of the results of the numerical analysis and the existing structural analysis of the metro tunnel showed, that the dimensioning of the existing tunnel is sufficient. The measured horizontal displacements of the tunnel blocks were less than $0.5 \mathrm{~cm}$. The measured maximum differential displacements at the joints of the tunnel blocks was $0.1 \mathrm{~cm}$.

Based on the results of the 2-dimenionsal and 3-dimensional numerical simulations no limitations of the serviceability and of course no damages were expected. The results of the monitoring program approved these results.

\section{Retaining system}

For the retaining system of the excavation in most cases bored pile walls have been used. The bored pile walls have been stabilized by struts or by anchors. The maximum depth of the excavation in the south-west of the project area (Panorama building) for up to 4 basement floors is $14.3 \mathrm{~m}$.

In order to adapt the retaining structure to the underground structures (sewer line and basement floors and retaining structures of the existing building) the piles with a diameter of $88 \mathrm{~cm}$ were combined with jet grouting columns to ensure a watertight pit and a maximum of flexibility regarding the difficult geometry.

Planning and design have been significantly influenced by the following aspects:

- sewer line directly beside the retaining wall;

- existing underground parking with up to 3 basement floors north of the sewer line;

- excavation for the buildings Palazzi (Figure 6) in the east;

- several cables and sewer lines in the south;

- metro tunnel in the west with a distance of about $20 \mathrm{~m}$;

- several remaining basements and former retaining systems.

In areas with existing basements behind the retaining system the upper level of anchors has been carried out with a back anchoring into the existing, back-filled basement. For the construction of the excavation in the south-west of the project area the following special geotechnical constructions have been carried out:

$-3,700 \mathrm{~m}$ piles for retaining wall, $\mathrm{d}=88 \mathrm{~cm}$;

$-10,500 \mathrm{~m}$ anchors for retaining wall;

$-290 \mathrm{~m}$ special bars for anchoring into the existing, back-filled basements;

$-36 \mathrm{t}$ of steel for struts and girder beams;

$-790 \mathrm{~m}$ foundation piles, $\mathrm{d}=150 \mathrm{~m}$;

$-415 \mathrm{~m}$ jet grout columns.

Figure 10 shows on the left the installation of the anchors and on the right the construction of the blinding concrete layer on the bottom of the excavation.
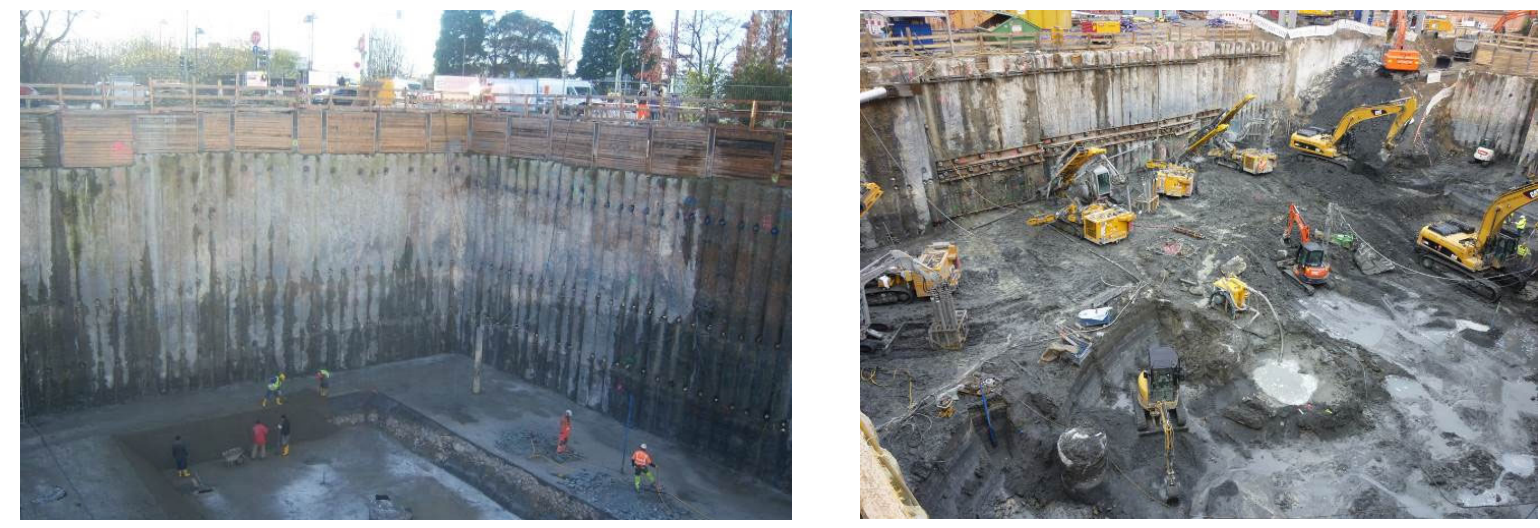

Figure 10. Calculated Iso-lines of the horizontal displacements (left) and the vertical displacements (right) 


\section{Conclusions}

The safety and quality assurance of geotechnical structures in urban areas is based on the following aspects:

- The soil investigation should include in-situ tests on the construction site. E.g. pile load test should be carried out for the verification of the skin friction and the base resistance.

- To consider the soil-structure interaction properly between new constructions and existing (underground-) structures 2-dimensional and 3-dimensional non-linear numerical simulations are necessary. In most cases the structure has to be include in the numerical model.

- The numerical simulations have to be calibrated, for example by the back analysis of pile load tests.

- For a sensitivity analysis the soil mechanical parameters should be varied.

- Bases on the observational method monitoring programs have to be developed to check the occurring displacements and to detect critical developments of the displacements and differential displacements.

- An independent peer review has to be applied. In addition to the structural peer reviewer a geotechnical peer reviewer has to be assigned.

\section{References}

Briaud, J.-L., Ballouz, M., \& Nasr, G. (2000). Static capacity prediction by dynamic methods for three bored piles. Journal of Geotechnical and Geoenvironmental Engineering, 126(7), 640-649. https://doi.org/10.1061/(ASCE)1090-0241(2000)126:7(640)

European Committee of Standardisation (CEN). (2008). Eurocode 7: Geotechnical design - Part 1: General Rules.

ISSMGE combined pile-raft foundation guideline. (2013). R. Katzenbach, \& D. Choudhury (Eds.). Darmstadt, Germany.

Katzenbach, R. (2005, May). Optimised design of high-rise building foundations in settlement-sensitive soils. In International Geotechnical Conference of Soil-Structure Interaction (pp. 39-46). St. Petersburg, Russia.

Katzenbach, R., Bachmann, G., Leppla, S. \& Ramm, H. (2010, June). Chances and limitations of the observational method in geotechnical monitoring. In Danube-European Conference on Geotechnical Engineering (13 p.). Bratislava, Slovakia.

Katzenbach, R., Leppla, S., \& Choudhury, D. (2016). Foundation systems for high-rise sturctures (1 ${ }^{\text {st }}$ ed.). New York, US. https://doi.org/10.1201/9781315368870 